\title{
Marine turf of an invasive alga expels lugworms from the lower shore
}

\author{
Karsten Reise ${ }^{1}\left[\right.$ D $\cdot$ Dagmar Lackschewitz $^{1} \cdot$ K. Mathias Wegner $^{1}$
}

Received: 7 July 2021 / Accepted: 29 November 2021 / Published online: 29 December 2021

(C) The Author(s) 2021

\begin{abstract}
Bare sandy flats at and below low tide level of the Wadden Sea (eastern North Sea, European Atlantic) were observed in 2020 to have been invaded by an introduced grass-like alga, Vaucheria cf. velutina (Xanthophyceae). A dense algal turf accumulated and stabilized mud, where resident seniors of the lugworm Arenicola marina had reworked rippled sand. Algae and worms were incompatible. Initially, rising patches with algal turf alternated with bare pits where lugworms crowded. Their bioturbation inhibited young algae, while the felt of established algal rhizoids clogged feeding funnels of worm burrows. Eventually, a mosaic pattern of competitors gave way to a coherent algal turf without lugworms. Concomitantly, a rich small-sized benthic fauna took advantage of the novel algal turf. This exotic Vaucheria may have the potential for drastically altering the ecological web at the lower shore.
\end{abstract}

Keywords Biological invasion $\cdot$ Bioengineering $\cdot$ Vaucheria $\cdot$ Arenicola $\cdot$ Competition $\cdot$ Facilitation

\section{Introduction}

In an increasingly interconnected human world, invasive alien species (IAS) transform ecological webs, particularly on island and coastal ecosystems (Anton et al. 2019; Bailey et al. 2020; Pyšek et al. 2020), which may entail high economic costs (Cuthbert et al. 2021). In marine and estuarine sediments, effects may escalate when alien sediment stabilizers rival with resident destabilizers for bioengineering dominance (Crooks 2002; Sousa et al. 2009; Guy-Haim et al. 2017).

Fringing the eastern North Sea, the Wadden Sea comprises estuaries, salt marshes and extensive tidal flats, sheltered by sand bars and barrier islands (Reise et al. 2010). The small filamentous algae of the genus Vaucheria (Xanthophyceae) were only known from uppermost shore, while none have been found around low tide level before until we found two near the island of Sylt in 2020 (Rybalka et al. 2022). $V$. longicaulis may constitute a complex of hidden species (Christensen 1996) and is assumed to have been introduced

\section{Responsible Editor: R.N. Cuthbert.}

Karsten Reise

karsten.reise@awi.de

1 Alfred Wegener Institute, Helmholtz Centre for Polar and Marine Research, Wadden Sea Station Sylt, Hafenstr. 43, 25992 List, Germany to the Dutch Rhine Delta in the 1990s (Stegenga et al. 2006), an estuarine region adjacent to the Wadden Sea. In contrast to this rather inconspicuous species, we also encountered another member of the genus Vaucheria, which grows in extensive turfs, accumulating mud at the transition between intertidal and subtidal sandy flats.

Based on plastid encoding $r b c \mathrm{~L}$-gene sequences and $p s b \mathrm{~A} / r b c \mathrm{~L}$ spacer region, this Vaucheria is distinct from that at upper shore salt marshes, although morphology suggests it may belong to the cosmopolitan $V$. velutina $\mathrm{C}$. Agardh 1824 (Rybalka et al. 2022). Most records are from upper shore, while Gallagher and Humm (1981) for the Golf of Florida, and Womersley (1987) and Wilcox (2012) for the southern Pacific, found V. velutina at lower shore positions. We suspect a complex of hidden species, and refer to the population of the lower shore near Sylt as $V$. cf. velutina, until a taxonomic revision based on specimen from various habitats and coastal regions worldwide untangles this complex.

We argue that $V$. cf. velutina is not native, but constitutes a recent introduction: (1) the Wadden Sea region has been exceptionally well surveyed for species of Vaucheria in the past (i.e., Simons 1975; Polderman 1979a, b; Krieg et al. 1988). It is highly unlikely that a conspicuous species like $V$. cf. velutina went unnoticed; (2) based on genetics, morphology and habitat, $V$. cf. velutina does not match any other of the 29 species recorded previously, making misidentification in previous investigations unlikely; (3) the Vaucheria bed 
we encountered in 2020 did not occur prior to 2018 (Reise et al. 2022). Given the steady influx of alien species into the Wadden Sea in recent decades, particularly by macroalgae from East-Asian coasts (Buschbaum et al. 2012; Lackschewitz et al. 2015, and in prep.), we assume $V$. cf. velutina originates from overseas.

In only 3 years, $V$. cf. velutina spread at four sites over an area of together 180 ha at the lee side of the island of Sylt in the northern Wadden Sea, generating bumpy mud with hummocks up to $20 \mathrm{~cm}$ higher than ambient sand flats (Reise et al. 2022). Green unicellular filaments, up to $8 \mathrm{~cm}$ long and with a mean density of $1.5 \mathrm{~mm}^{-2}$, are anchored by felted rhyzoids down to $5 \mathrm{~cm}$ in the sediment. The accumulated mud persists as hummocks or plateaus. Thalli overwintering in the sediment give rise to a new green turf next summer. In that study (Reise et al. 2022), we addressed changes in habitat structure and sediment composition, while here we consider the biological impacts with a particular focus on Arenicola.

The spread of $V$. cf. velutina (hereafter called simply Vaucheria) at the lower sandy shore in the Wadden Sea constitutes a paradox. On these sand flats, the large sedentary polychaete Arenicola marina L. abounds, reworking and irrigating the sediment (Reise 1985). This activity seems incompatible with sediment-stabilizing Vaucheria. Resident lugworms recycle the upper layer of sediment 10-20 times per year through their guts (Cadée 1976). They keep the sand permeable and oxygenated, increase mineralization and benthic-pelagic exchange processes (Volkenborn et al. 2007), with cascading effects on associated benthos (i.e., Reise 1985; Flach 1992; Volkenborn and Reise 2007; Volkenborn et al. 2009; Kuhnert et al. 2010; Lei et al. 2010; Suykerbuyk et al. 2012). Feeding funnels with downward sliding surface sediment and mounds of fecal strings with ejections about every half hour cause an unstable upper sediment layer (Riisgård and Banta 1998; Wendelboe et al. 2013). Such a habitat should be entirely unsuitable for a small and slender alga to become established.

We here present data indicating a regime shift from marine sandy bottom reworked by resident lugworms Arenicola marina toward a muddy turf generated by a sediment-stabilizing alga introduced from overseas. This is a striking example for ecological change in the wake of an unintentionally translocated species. However, at the lower shore, where the largest lugworms dwell, their density is modest compared with much higher densities of juveniles and adults at the upper shore (Beukema and de Vlas 1979; Farke et al. 1979; Lackschewitz and Reise 1998; Reise et al. 2001). We hypothesize (1) that the low density of those senior lugworms at the lower shore leaves gaps with sufficiently stable sediment for colonizing Vaucheria. This may explain the absence of Vaucheria further up on the shore where abundance of Arenicola is high, although
Vaucheria may also avoid prolonged tidal exposure. Some small tube-building polychaetes and amphipods manage to coexist with Arenicola in spite of the sediment instability on lugworm flats (Flach 1992; Lackschewitz and Reise 1998). May such coexistence also be possible for Vaucheria? We hypothesize (2) that alternating patches of Vaucheria and Arenicola may allow for coexistence at the lower shore. The alternative would be that interference competition between such antagonistic benthic bioengineers inevitably leads to exclusion.

Although we observed senior lugworms and Vaucheria at the same tidal level, their contrasting effects on sediment composition and bedform morphology (Reise et al. 2022) likely entail a shift in associated benthic community structure. We hypothesize (3) that the dense turf of Vaucheria with long rhyzoids provides shelter and food for small zoobenthos. On the other hand, mud accumulated by Vaucheria may be hostile for benthic fauna requiring oxygenated sediment.

\section{Methods}

\section{Study site}

List tidal basin at the Danish-German boundary (eastern North Sea, northern Wadden Sea) comprises $400 \mathrm{~km}^{2}$ with vast intertidal and shallow subtidal flats, intersected by deep channels (Gätje and Reise 1998). It extends north of a causeway connecting the island of Sylt with the mainland (Fig. 1A). Tides are semi-diurnal with a range of almost $2 \mathrm{~m}$. Salinity ranges from 26 to 32 , and mean water temperatures from 0 to $20{ }^{\circ} \mathrm{C}$ with a recent warming of $1{ }^{\circ} \mathrm{C}$ since the 1980s (Rick et al. 2022). We first discovered muddy beds of Vaucheria cf. velutina in June 2020 at shoals in Blidsel Bay, east of northern Sylt $\left(54^{\circ} 97^{\prime} \mathrm{N}, 08^{\circ} 38^{\prime} \mathrm{E}\right.$; Rybalka et al., submitted; Reise et al. 2022).

At Blidsel Bay, the upper shore is sandy with large diagonal sand waves (Fig. 1B), passing over into shallow subtidal beds of Sargassum muticum and of mixed mussels and oysters. Further seaward at the lower shore, dark Vaucheria beds show sharp boundaries where adjoining bright sand bars. We encountered Vaucheria from +0.2 to $-0.5 \mathrm{~m}$ relative to mean low tide level. Exposure to air was limited to spring low tides, combining with offshore winds. Our time of access was rather short and never more than $2 \mathrm{~h}$ per low tide period. During neap tides and onshore winds, the Vaucheria beds remained submerged. At Blidsel Bay, the Vaucheria bed established in 2018 and 2019 (Reise et al. 2022), and since June 2020 spread further into surrounding lugworm flats, visible from the air as wide blotchy belt in front of a distinct boundary of the old bed (Fig. 1C, lower right). 


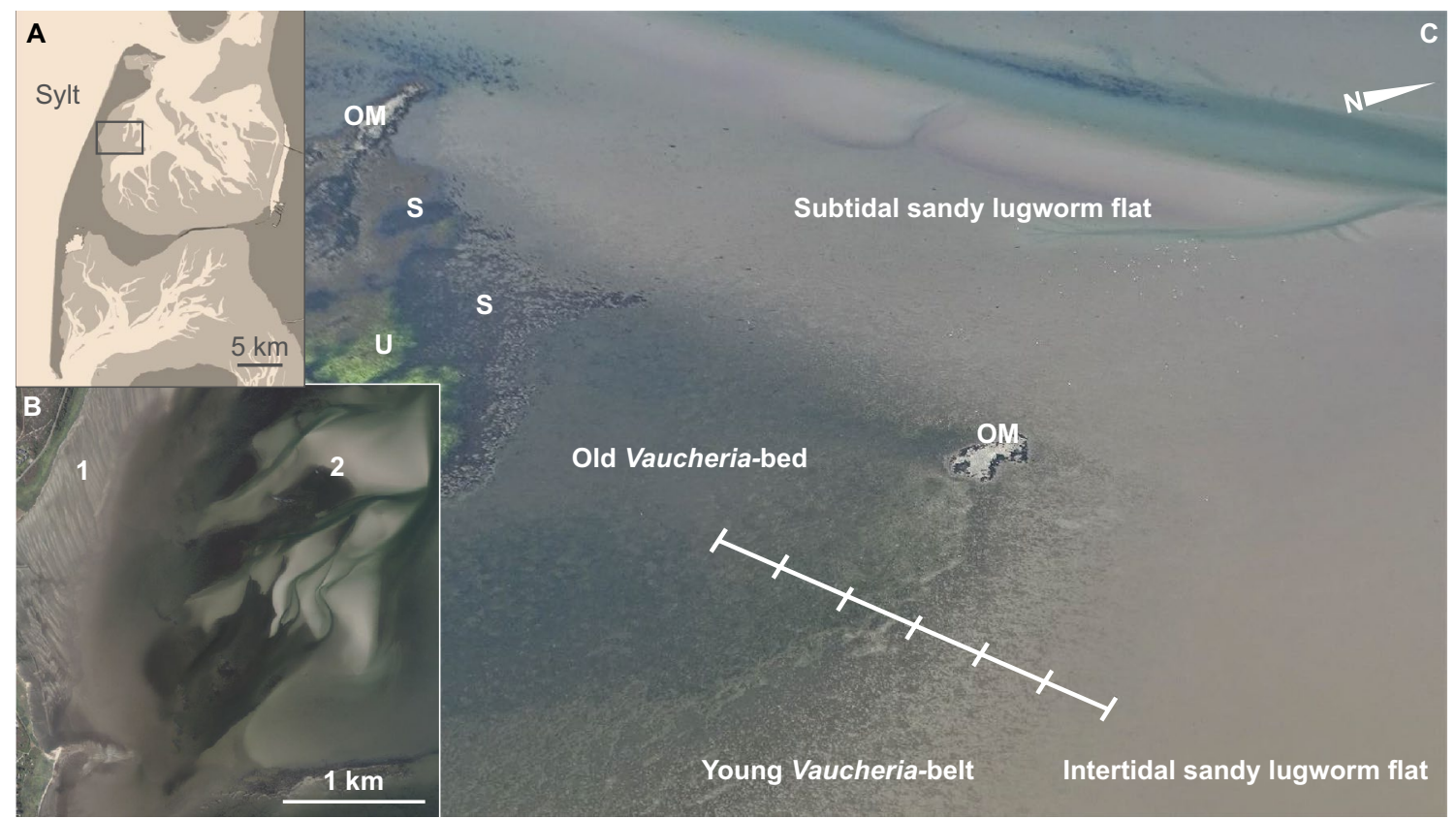

Fig. 1 Study site. A Island of Sylt with tidal flats shaded. For rectangle see B aerial image (August 2020) showing the upper tidal flats (sample site 1), dark subtidal Sargassum beds and mixed mussel and oyster beds, while the dark areas adjacent to bright seaward sand bars depict Vaucheria beds (sample site 2), discernible in the closeup

\section{Why could Vaucheria conquer lugworm flats at the lower shore?}

We compared the sub-population of A. marina at the upper shore (about mean tide level), where we found no Vaucheria, with the sub-population at the lower shore (spring low tide level), where we encountered an expanding Vaucheria bed in June 2020 (Fig. 1B, site 1 and 2). The aim was to infer different levels of bioturbation from Arenicola size and abundance. We randomly dug eight worms at each site in June 2020. When relaxed in seawater, we measured lengths, then put worms on blotting paper and determined their individual volume in a calibrated cylinder to nearest $0.1 \mathrm{~cm}^{3}$. For additional comparisons of mean lugworm size, we measured diameters of fecal strings to the nearest millimeter (Reise et al. 2001) at 20 fecal mounds of each site. As a proxy for abundance, we counted fecal mounds at the end of low tide exposure, using randomly spread $0.25-\mathrm{m}^{2}$ frames, 15 times at upper and 20 times at lower shore (Fig. 1B, site 1 and 2, respectively).

When we encountered an established Vaucheria bed for the first time on June 03 in 2020, muddy hummocks with a dense turf formed a distinct boundary with the adjoining bare lugworm flat in the north (Fig. 1B, site 2). On the second visit on June 10, barely recognizable sand wave ridges became visible when tidal emergence commenced, alternating with pits. Ridges seemed to have less fecal mounds aerial view $\mathbf{C}$ there positioned between two oyssel beds (OM: oysters and mussels mixed), Sargassum muticum (S) and lattice-shaped Ulva (U). The 150-m long transect line with 25-m intervals runs from old (since 2018-2019) through young growth (since June 2020) of Vaucheria into surrounding bare sand. Arrow points north

than pits. However, we were not able to quantify this with our $0.25-\mathrm{m}^{2}$ frame because of gradual transitions between ridges and pits. At the same time, we observed close to the Vaucheria bed a faint shine of green filaments on ridges and never in pits. Already by June 17, a mosaic of bare pits and slightly elevated plateaus with a turf of Vaucheria was apparent in front of the northern and western edge of the bed (see blotchy areas in Fig. 1C and irregular patches of bare sand within an algal cover on the lugworm flat in Fig. 2A). Later in June, this weakly pronounced pattern developed into a distinct mosaic (Fig. 2A). On June 17 in 2020, we counted fecal mound abundance at 10 bare pits and 10 elevated plateaus overgrown with Vaucheria, using the $0.25-\mathrm{m}^{2}$ frame.

\section{Do Vaucheria and Arenicola coexist in spite of interference competition?}

Assuming that the central part of the Vaucheria bed constitutes a late succession stage compared to the belt with young growth, we also counted fecal mounds there. Due to low numbers, we randomly selected 6 squares of $10 \mathrm{~m}^{2}$ for estimating fecal mound abundance (June 2020). For further exploring abundance of Arenicola in response to developing growth of Vaucheria, we repeated counting fecal mounds in August 2020. Vaucheria at the belt with young growth now had also invaded the formerly bare pits (see Fig. 2B). To account for low abundance and patchiness, we used a 
Fig. 2 Vaucheria cf. velutina advancing in a mosaic fashion on a sand flat of the lower shore in Blidsel Bay, June 2020. A Plateaus with dense algal turf alternated with lighter pits occupied by Arenicola marina. B In the course of summer, algae also spread at pits. C Algae clogged feeding funnels of lugworms (arrow), while lugworms deposited fecal castings upon algal turf. D Algal turf in July 2020. E Algal tuft cleaned from sediment, green filaments above and a felt of pink rhizoids below. Thicker than rhizoids are entangled tubes of spionid worms
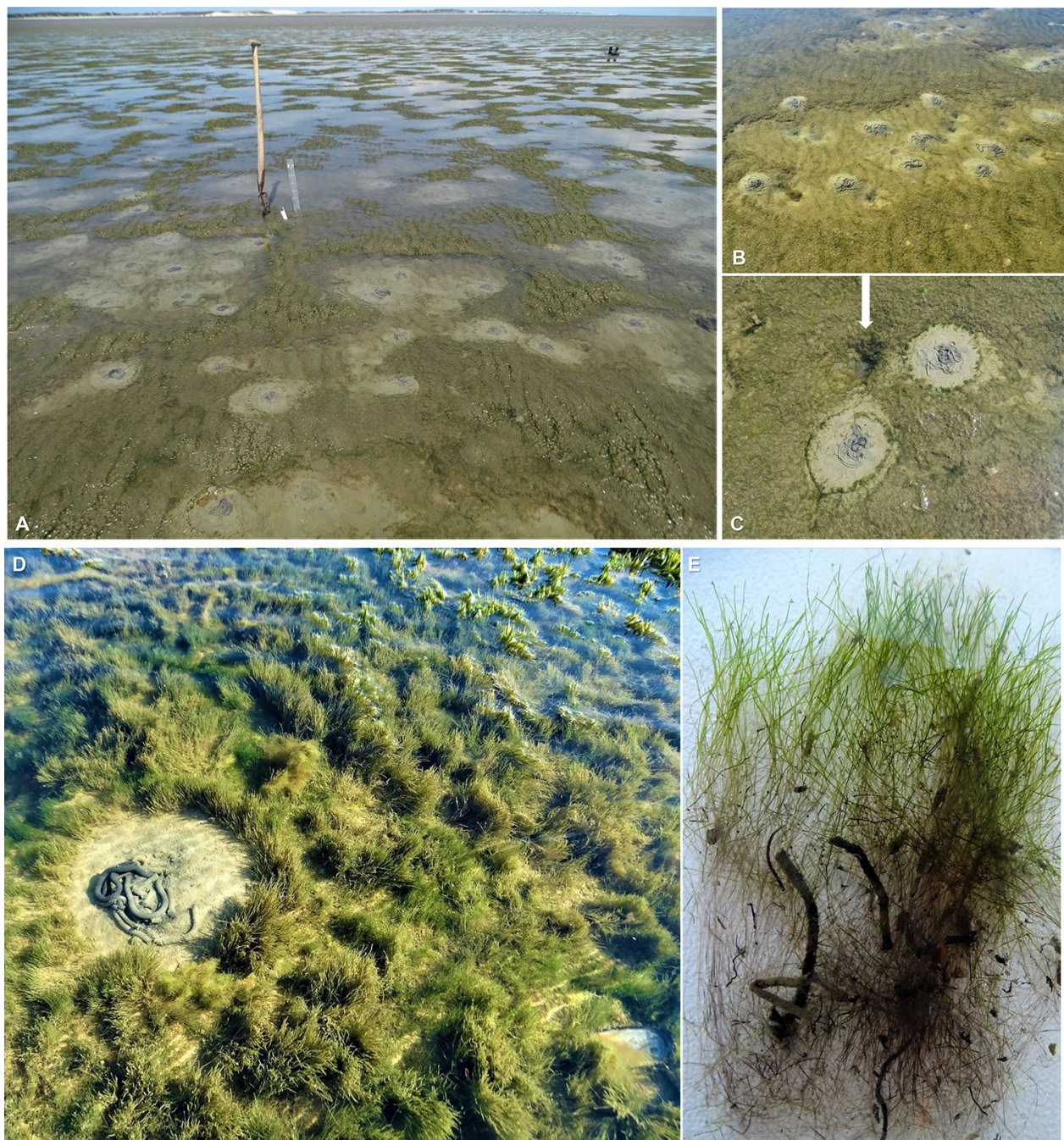

1- $\mathrm{m}^{2}$ frame, randomly replicated 60 times for counting fecal mounds. For comparison, we also counted in the central part of the Vaucheria bed, this time using a $1-\mathrm{m}^{2}$ frame 40 times. On the bare sand flat north of the Vaucheria bed with higher abundances of fecal mounds, we counted them by randomly replicating a frame of $0.25 \mathrm{~m}^{2} 60$ times.

To explore the quantitative relation between Arenicola and Vaucheria on more refined scale, we sampled at 25-m intervals along a transect perpendicular to the conspicuous boundary of the established Vaucheria bed. We chose as position of the transect, where the belt of young growth extended approximately $50 \mathrm{~m}$ into the adjacent lugworm flat on June 23, 2020 (Fig. 1C). This transect reached from the central old bed across the pioneer belt into the bare lugworm flat adjoining the Vaucheria bed in the northern direction.

We again estimated abundance of Arenicola by counting fecal mounds with a $0.25-\mathrm{m}^{2}$ frame, replicated 20 times at each transect interval, randomly along $20 \mathrm{~m}$ perpendicular to transect line. To measure Vaucheria, tubes of $10 \mathrm{~cm}^{2}$ cross section with sharpened lower edge, we gently drilled through the algal turf to a depth of $5 \mathrm{~cm}$. This was replicated three times at each transect interval. After washing the obtained sediment cores through a $125-\mu \mathrm{m}$ mesh, we picked up algal tufts with forceps (Fig. 2E). To remove adhering sand grains, we continued washing under running tap water. Entangled tubes of spionid worms and other algae (mainly Rhizoclonium and Ectocarpus) we removed manually when present (see Fig. 3). We then spread the tufts of Vaucheria on blotting paper, exposed for $6 \mathrm{~h}$ to bright sunlight to dry. Weights obtained to nearest $\mathrm{mg}$ we employed as a rough proxy for the phytomass of Vaucheria.

\section{What zoobenthic shift is associated with advancing Vaucheria?}

To compare benthic fauna between the adjacent bare sandy lugworm flat (50 $\mathrm{m}$ to the north) with that within the dense turf of Vaucheria (50 $\mathrm{m}$ inside the bed from the old edge), we randomly sampled both habitats for live meio-, mesoand macrofauna. For obligatory and temporary meiofauna, 
Fig. 3 Brownish braids of Ectocarpus at Vaucheria hummocks (A) and wads of green Rhizoclonium (B) with floating mud snails Peringia ulvae (light dots) between tufts of Vaucheria, Blidsel Bay in July 2020
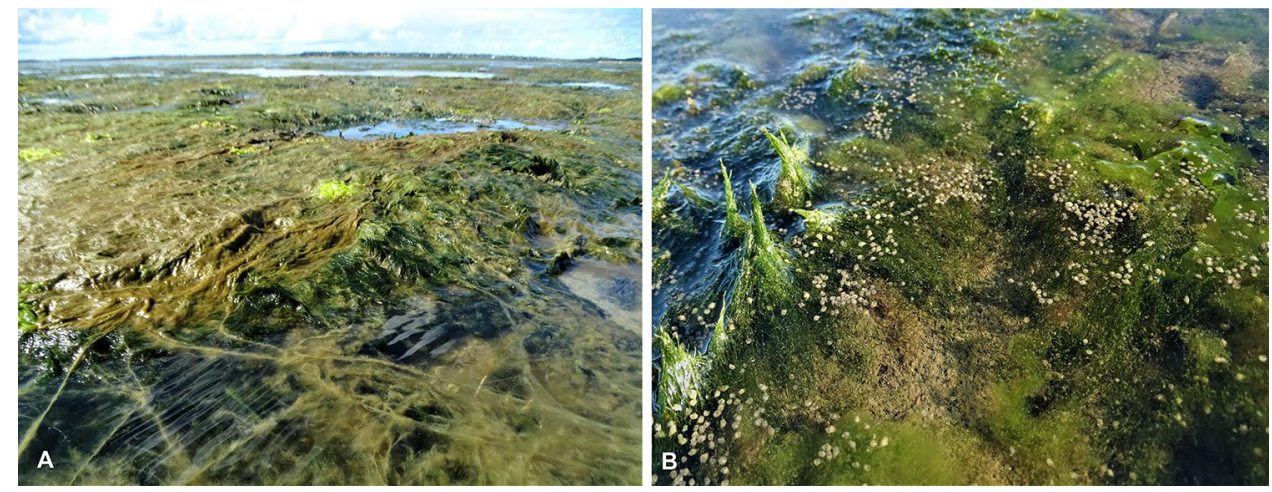

we repeatedly filled a beaker with $1 \mathrm{~cm}^{3}\left(1 \mathrm{~cm}^{2}\right.$ core to $1 \mathrm{~cm}$ depth) sample of surface sediment with filtered seawater, stirred it, and then decanted through a $63-\mu \mathrm{m}$ mesh several times until no more animals were retained. In addition, we also inspected the residual sand. We pipetted individuals from petri dishes under a stereo microscope, identified permanent meiofauna (taxa passing a $250-\mu \mathrm{m}$ mesh even as adults) to major taxon and temporary meiofauna (the young of macrofauna passing a $250-\mu \mathrm{m}$ mesh) to species level, and then counted. We took four replicates from bare sand and four from the Vaucheria turf on June 17 in 2020.

For mesofauna (small-sized macrofauna) retained by a $250-\mu \mathrm{m}$ mesh, we washed $10-\mathrm{cm}^{2}$ sediment cores (depth from surface to $5 \mathrm{~cm}$ ) in seawater. We picked the individuals with forceps from white dishes with the sieve residue, identified and counted them to species level under a stereo microscope. We took 6 replicates from bare sand and 6 from the Vaucheria turf (see above) on June 12 in 2020. To assess mesofauna specifically associated with aboveground green siphons of Vaucheria (see Fig. 2E), these were clipped at the sediment-water interface on 6 areas of $50 \mathrm{~cm}^{2}$ and then washed over a $125-\mu \mathrm{m}$ mesh. For further treatment see above.

To retain larger macrofauna, we sieved cores of $50 \mathrm{~cm}^{2}$ (depth from surface to $20 \mathrm{~cm}$ ) through a $1-\mathrm{mm}$ mesh in the field. We randomly took ten replicates from bare sand 50-100 m north of the Vaucheria bed, 10 from inside the bed at muddy hummocks with a dense turf, and 10 from sandy troughs between hummocks with sparse and patchy growth of Vaucheria (July 13-22 in 2020).

On the exposed sand flats at and below low tide level, we usually encountered no macroalgae, while the Vaucheria bed intermittently accumulated drift algae between July and September (Fig. 3). Since their presence was mainly transient, we only qualitatively recorded the taxa observed with notes on their relative abundance. We add this information because of potential effects on fauna dwelling in the Vaucheria bed.

\section{Statistical analyses}

For the upper vs. lower shore comparisons we analysed lugworm volume, lugworm length and fecal diameter as linear models. Number of mounds was analysed as a poisson distributed generalized linear model (GLM). For the transect analysis, transect intervals were transformed into a single 7-level factor. Mounds per $\mathrm{m}^{-2}$ were analysed as a poisson distributed GLM, while Vaucheria mass was analysed as a linear model. All model fits were checked for high leverage values and predictor bias by inspecting residual vs. fitted and normal Q-Q plots. After detecting significant variation between all intervals, pairwise post-hoc tests were used to identify significant differences among interval pairs using Tukey contrasts implemented in the multcomp package. Pearson's product-moment correlation was applied to detect inverse relation between Arenicola-mound abundance and Vaucheria mass. To compare community composition associated to the different habitat types we used Permutational Multivariate Analysis of variance (PERMANOVA) based on Bray-Curtis distance matrices implemented in the adonis function of the vegan package, followed by simper analysis to identify taxa contributing most to community differentiation. Community composition was visualised by non-metric multidimensional scaling (NMDS) using the metaMDS function. All analyses were performed using the R statistical environment (R Core Team 2021).

\section{Results}

\section{Why could Vaucheria conquer lugworm flats at the lower shore?}

When comparing the lugworm population at upper and lower shore sand flats near the island of Sylt (Fig. 1B, site 1 and 2), mean worm size increases and abundance decreases from upper to lower shore (Table 1). Dug up worms from their deep $(>20 \mathrm{~cm})$ burrows at lower shore were on average 
Table 1 Arenicola marina size and abundance at Blidsel Bay upper and lower shore in June 2020

\begin{tabular}{lcc}
\hline Blidsel Bay & Upper shore & Lower shore \\
\hline Volume of lugworms $\left(\mathrm{cm}^{3}\right)$ & $4.1 \pm 1.4$ [range 2-6] & $12.9 \pm 3.4$ [range 8-19]*** \\
Length of lugworms $(\mathrm{cm})$ & $12.7 \pm 2.3$ [range 9-16] & $20.5 \pm 3.4$ [range 17-26]*** \\
Fecal string diameter $(\mathrm{mm})$ & $2.8 \pm 0.5$ [range 2-4] & $4.8 \pm 0.9$ [range 3-6]*** \\
Fecal mounds $0.25 \mathrm{~m}^{-2}$ & $9.5 \pm 2.1$ [range 7-14] **** $^{* *}$ & $2.2 \pm 1.3$ [range 0-4] \\
\hline
\end{tabular}

Means \pm standard deviation and range of data []; *** significantly $(p<0.001)$ higher values. Lugworm volume, length and string diameter analyzed as linear model, and fecal mound abundance as generalized linear model with Poisson distribution 3-times bigger and 2-times longer than lugworms dug at the upper shore site in June 2020. Mean size difference was also apparent from diameters of defecated strings of sand. On the other hand, abundance of fecal mounds was 4-times lower at the lower shore compared to upper shore (Table 1). Young lugworms were notably absent from lower shore. When multiplying individual worm volumes with fecal mound abundance, the obtained total biovolume of lugworms per $\mathrm{m}^{2}$ was $156 \pm 12 \mathrm{~cm}^{3}$ at the upper and only $114 \pm 18 \mathrm{~cm}^{3}$ at the lower shore, suggesting $27 \%$ less sediment reworking. Furthermore, coefficient of variation (SD/mean) of fecal mound abundance at $0.25-\mathrm{m}^{2}$ scale was $59 \%$ at lower shore compared to only $22 \%$ at upper shore. Although hardly recognizable, parallel ridges of sand waves at $\mathrm{m}$-scale seemed to have less lugworm castings than wet depressions between them. However, counting fecal mounds on the scale of $0.25 \mathrm{~m}^{2}$ could not reveal this because of gradual transitions between ridges and pits in between.

At June 17 in 2020, fecal mounds of lugworms concentrated at bare pits with $15.6 \pm 3.6$ [range $12-20$ ] $\mathrm{m}^{-2}$, while at the slightly higher vegetated plateaus castings were almost absent $(0.4 \pm 1.2$ [range $\left.0-4] \mathrm{m}^{-2}\right)(\mathrm{GLM}, z=8.499$, $p<0.001)$, scaled up from $0.25-\mathrm{m}^{2}$ counting squares. Assuming a roughly equal share of pit and plateau area (Fig. 2A), combined abundance of fecal mounds $\left(8\right.$ per $\left.\mathrm{m}^{2}\right)$ was similar to that of the bare sand flat further north ( 8.8 per $\mathrm{m}^{2}$, see Table 1).

\section{Do Vaucheria and Arenicola coexist in spite of interference competition?}

The detrimental effects of the algal turf on lugworm abundance is apparent from their near absence from the central part of the bed $\left(<1 \mathrm{~m}^{-2}\right)$. By July 2020 , the mosaic pattern in the belt of young growth gradually became blurred (Fig. 2B), and in August the overall abundance of fecal mounds had decreased by $59 \%$ since June. Abundance was now only $3.3 \pm 1.9 \mathrm{~m}^{-2}$. During the same time, abundance of fecal mound on the adjacent bare sand flat had increased to $18.4 \pm 6.0 \mathrm{~m}^{-2}$. In the central part of the bed, fecal mound abundance remained $<1 \mathrm{~m}^{-2}$.

An inverse relationship between lugworms and the algal turf was also apparent along a transect running from bare sand flat habitat into the old Vaucheria bed (Fig. 4). This transect runs across patches of young Vaucheria growth alternating with lugworms in pits, and from there further to old hummocks covered by a dense turf, alternating with patchy growth in troughs between these hummocks. Note that in Fig. 4, we scaled up data to $\mathrm{m}^{2}$ from counting areas of $0.25 \mathrm{~m}^{2}$ for lugworm fecal mounds, and from sediment
Fig. 4 Abundance of Arenicola marina fecal mounds (columns, means with standard deviation; same letters above each transect interval indicate a lack of significant Tukey contrasts in multiple comparisons of means) and phytomass of Vaucheria cf. velutina (green line; vertical bars refer to standard deviation), along a transect from bare sand flat (left) across a belt of young algal growth and into hummocks and troughs within old growth (right). Data were collected at Blidsel Bay at Sylt, June 23 in 2020

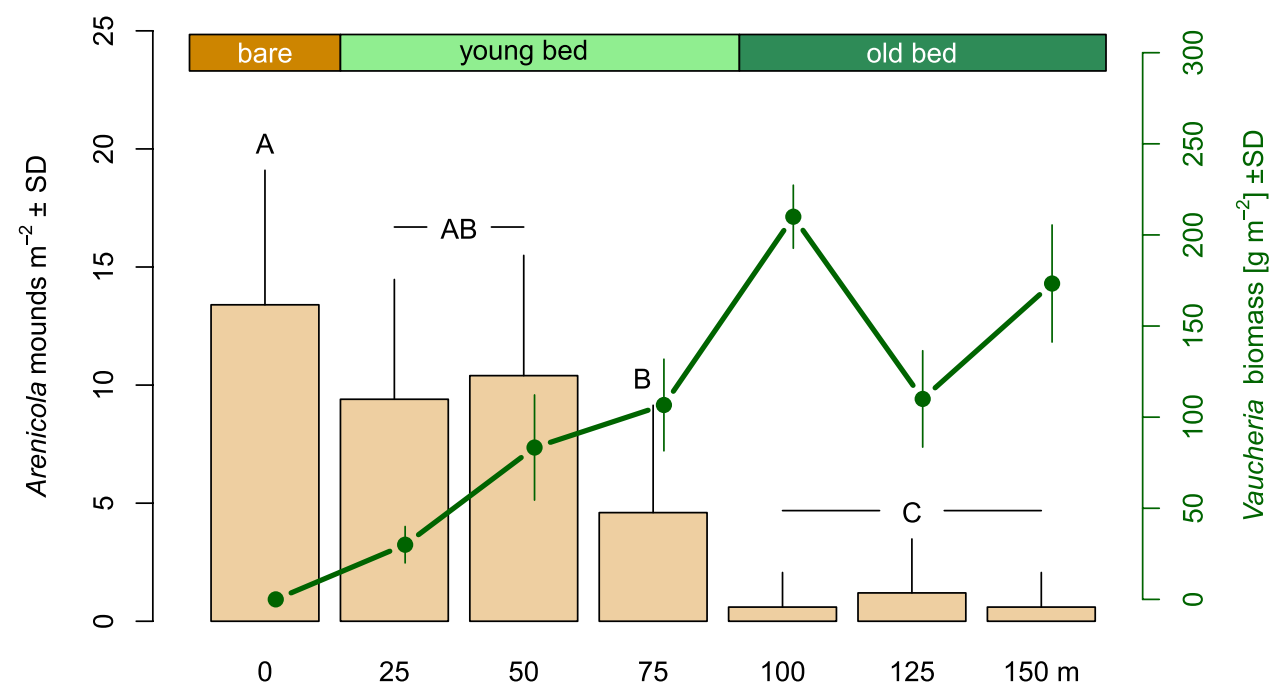


cores of $10 \mathrm{~cm}^{2}$ for dry weight of Vaucheria. This exaggerates variance because patchiness decreased from small to larger scale. Some lugworms persisted in troughs but none on hummocks. We found a significant inverse relation between Arenicola abundance and Vaucheria mass (Pearson's product-moment correlation, $R=-0.891, t=-4.400$, $p=0.007)$.

\section{What zoobenthic shift is associated with advancing Vaucheria?}

Abundance of major groups of permanent meiofauna (i.e., Nematoda, Copepoda, Ostracoda) retained by a $62-\mu \mathrm{m}$ mesh did not differ significantly between bare sand habitat and dense algal turf $\left(R^{2}=0.151\right.$, Pseudo- $\left.F_{1,7}=1.067, p=0.344\right)$. On the other hand, temporary meiofauna, juveniles of the macrofauna in the meiofaunal size range (Polychaeta and Mollusca) occurred with $17 \pm 7$ individuals per $\mathrm{cm}^{2}$ (range $8-24$ ) in the algal turf and with $<1$ (range $0-1$ ) in bare sand. Consequently, communities differed strongly between sites $\left(R^{2}=0.706\right)$, but not significantly (Pseudo- $F_{1,4}=7.192$, $p=0.2$ ) because three out of the four sand flat sites dropped out of the analyses due to missing data. Most were juvenile mud snails Peringia ulvae crawling on green filaments. This was also apparent in the mesofauna on clipped filaments of Vaucheria. Young mud snails dominated with $79 \%$ over other juvenile macrofauna (8\% bivalves, 5\% small and juvenile Annelida, 4\% young Malacostraca). Small sea slugs of the species Alderia modesta and one Limapontia depressa contributed another $4 \%$. These slugs were small $(<5 \mathrm{~mm})$ but already produced egg masses attached to filaments of Vaucheria (own observation).

Small macrofauna (mesofauna) retained by a $250-\mu \mathrm{m}$ mesh was 4-times more numerous and 3-times richer in species within algal turf than on bare sand flat (Table 2). Mainly small annelid worms and young bivalves contributed to high abundances at the algal turf. Most of the young $P$. ulvae passed through this mesh. Simper analysis assigns highest influence to the annelids Streblospio benedicti, Tubificoides benedeni and Pygospio elegans. Accordingly, the species assemblages of the two habitats were significantly different $\left(R^{2}=0.382\right.$, Pseudo- $\left.F_{1,11}=6.190, p=0.002\right)$ and clearly separated in the MDS plot (Fig. 5).

Macrofauna retained by a $1-\mathrm{mm}$ mesh is compared between the three habitats bare sand flat, and troughs and hummocks within the old Vaucheria bed (Table 3). At the bare sand flat, macrofauna was rather poor in abundance and species richness, compared to the patchy algal turf in troughs and dense algal turf on hummocks. At hummocks, abundance was 20 times higher than in bare sand. Troughs with a moderate or very patchy turf showed intermediate abundances and species composition between hummocks and bare sand north of the Vaucheria bed. As shown in Table 3
Table 2 Mesofauna (small macrofauna) $10 \mathrm{~cm}^{-2}(0-5 \mathrm{~cm}$ depth) retained by $250-\mu \mathrm{m}$ mesh at bare sand flat and at algal turf on muddy hummocks, June 12 in 2020

\begin{tabular}{lll}
\hline Habitat & Sand flat & Algal turf \\
\hline All individuals & $2.33 \pm 2.34[1-7]$ & $10.33 \pm 2.80[7-14]$ \\
Species richness & $1.83 \pm 1.17[1-4]$ & $6.00 \pm 1.67[4-9]$ \\
Sum of species & 4 & 14 \\
Pygospio elegans $(0.15)$ & $0.67 \pm 0.52[0-1]$ & $2.17 \pm 1.17[1-4]$ \\
Streblospio benedicti $(0.19)$ & 0 & $2.00 \pm 1.26[0-3]$ \\
Tubificoides benedeni $(0.17)$ & 0 & $1.83 \pm 0.98[0-3]$ \\
Juvenile mollusca (4 species) & $0.17 \pm 0.41[0-1]$ & $3.00 \pm 2.00[0-6]$ \\
(cumulative contribution: & & \\
0.24) & & \\
\hline
\end{tabular}

In addition to total abundances and species richness, we show the three most influential species based on Simper analysis, and lumped juvenile mollusks

Given are means \pm standard deviation and range of data []. Number behind species names give their respective contribution to community differentiation between sand flats and algal turfs

by standard deviations and wide ranges of data, macrofauna was highly patchy at the $50-\mathrm{cm}^{2}$ scale, most conspicuous at the troughs with patchy growth of Vaucheria. Only amphipods, mainly Urothoe poseidonis, known to be associated with lugworm burrows (Lackschewitz and Reise 1998), were more abundant in bare sand and there comprised $76 \%$ of all individuals. Annelids dominated entirely at troughs and hummocks, mostly with tube-dwellers. Among those, Pygospio elegans occurred at all three habitats but was most abundant in dense algal turf, together with Streblospio benedicti. Of tube-dwellers, the 1-mm mesh retained also relatively small individuals because tubes entangle in tufts of Vaucheria. Overall, we found significant differences in community composition between the three habitats $\left(R^{2}=0.407\right.$, Pseudo$\left.F_{2,28}=8.936, p=0.001\right)$. Differentiation was mainly caused by differences between sand flats and Vaucheria hummocks, while the assemblage at troughs partly overlapped with the other two (Fig. 5).

Drift algae accumulated intermittently from July to September on the Vaucheria bed (Fig. 3). Of these, Rhizoclonium riparium and Ectocarpus spp. were the most persistent. The latter grew massively as epiphytes in adjacent kelp beds on Sargassum muticum, and probably drifted from there to the Vaucheria bed. Other species were more ephemeral but frequent at times: Cladophora albida, Ulva spp., Gracilaria vermiculophylla, Dasya bailouviana, Heterosiphonia (Dasysiphonia) japonica, Porphyra sp., Ceramium virgatum (rubrum), Polysiphonia sp., Fucus vesiculosus, Elachista fucicola, Sargassum muticum and Dictyota dichotoma. Although these drifting macroalgae could cover the Vaucheria bed at times, they rarely stayed more than a week because a next rough weather event took them off again. We detected no effects on Vaucheria due to smothering. 
Fig. 5 MDS plot for the small macrofauna retained by a 250- $\mu \mathrm{m}$ mesh (mesofauna, stress $=0.068$ ) and macrofauna retained by a $1-\mathrm{mm}$ mesh (stress $=0.110$ ). At the sand flat in the upper panel two points coincide. For further explanations, see Table 2 and 3
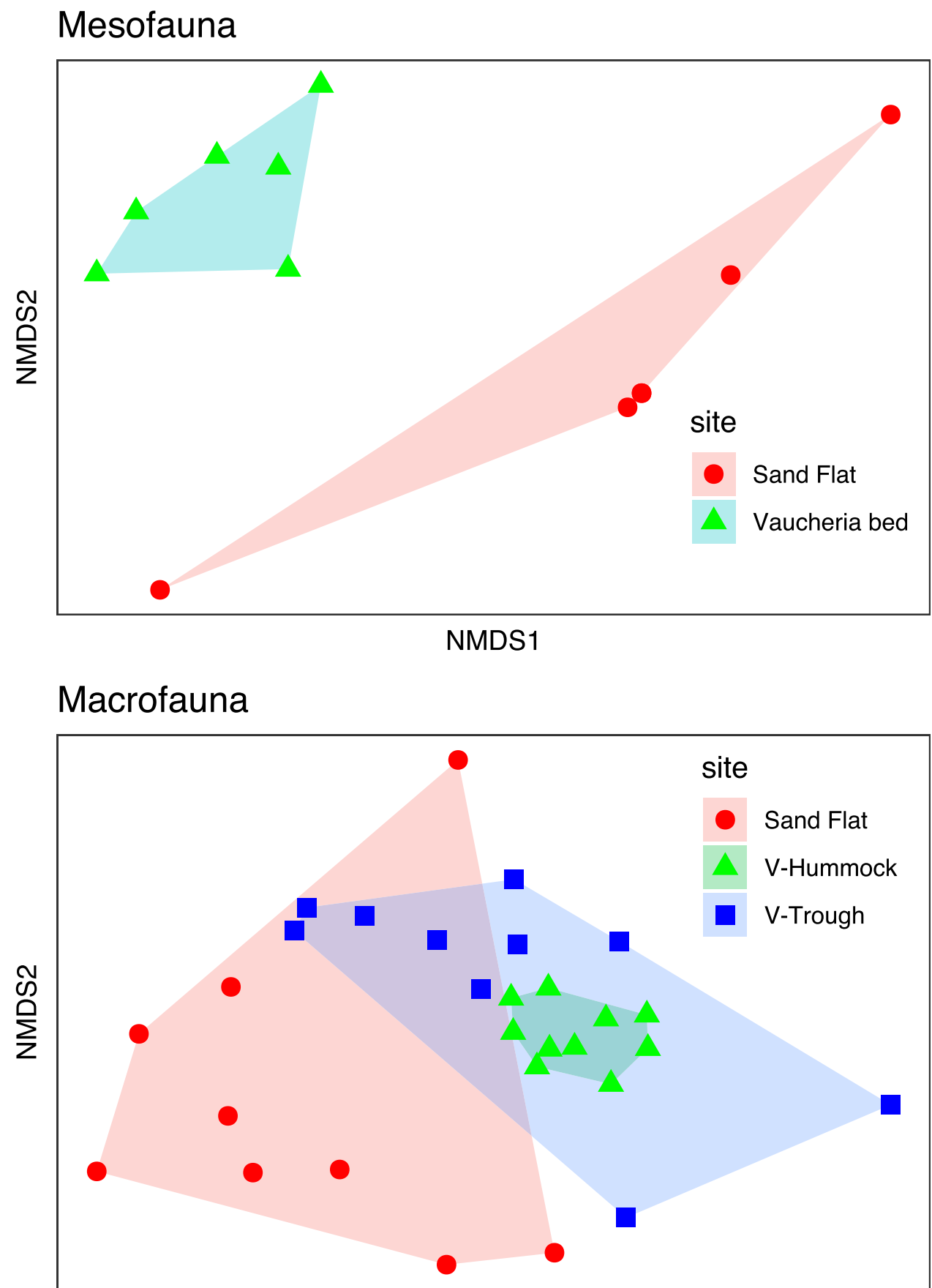

NMDS1

\section{Discussion}

This study describes the beginning of a potential displacement of the most characteristic benthic species in the European Wadden Sea, the lugworm Arenicola marina, from the lower shore by an invasive alga forming dense turfs and accumulating mud where loose sand prevailed before.

\section{Contest between invading Vaucheria and resident Arenicola}

Why could Vaucheria invade lugworm flats at the lower shore in spite of the bioturbation activity of Arenicola? Lugworm abundance at upper shore is higher than at lower shore where we found Vaucheria. From the Wadden Sea, a general pattern with a belt of young Arenicola at the uppermost 
Table 3 Macrofauna $50 \mathrm{~cm}^{-2}$ $(0-20 \mathrm{~cm}$ depth) retained by a 1-mm mesh at bare sand flat, at troughs with patchy Vaucheria between muddy hummocks with a dense cover of Vaucheria, July in 2020

\begin{tabular}{llll}
\hline & & Algal turf & \\
\cline { 3 - 4 } Habitat & Bare sand flat & Troughs & Hummocks \\
\hline All individuals & $5.1 \pm 5[0-15]$ & $19.1 \pm 22.6[1-48]$ & $104.6 \pm 21.5[83-138]$ \\
Species richness & $2.3 \pm 1.2[0-4]$ & $4.6 \pm 2.9[1-10]$ & $8.4 \pm 2.4[6-12]$ \\
Sum of species & 9 & 16 & 23 \\
Urothoe poseidonis & $2.9 \pm 4.3[0-14]$ & 0 & 0 \\
SF-T: 0.20 & & & $0.8 \pm 1.3[0-3]$ \\
Scoloplos armiger & $0.2 \pm 0.4[0-1]$ & $1.8 \pm 1.5[0-4]$ & \\
SF-T: 0.14 & & & $54.8 \pm 21.5[24-85]$ \\
Pygospio elegans & $0.5 \pm 0.7[0-2]$ & $3.9 \pm 5.0[0-14]$ & \\
SF-T: 0.13, SF-H: 0.43, T-H: 0.46 & & & $40.1 \pm 12.1[19-56]$ \\
Streblospio benedicti & 0 & $9.8 \pm 15.2[0-39]$ & \\
SF-T: 0.23, SF-H: 0.37, T-H: 0.35 & & & \\
\hline
\end{tabular}

Below total abundances and species richness of the three assemblages, and the four most influential species based on Simper analysis are given

Given are means \pm standard deviation and range of data []. Number under species names give their respective contribution to community differentiation in the pairwise comparisons sand flat vs. trough (SF-T), sand flat vs. hummock $(\mathrm{SF}-\mathrm{H})$ and trough vs. hummock $(\mathrm{T}-\mathrm{H})$ shore, high adult abundance from upper to lower shore, and low abundance of the largest or 'senior' lugworms further offshore, is well known (i.e., Farke et al. 1979; Flach and Beukema 1994; Reise et al. 2001). Lugworm exclusion experiments (Volkenborn et al. 2009) and observations at patchy freshwater seeps avoided by lugworms (Zipperle and Reise 2005) have shown that tube builders and species requiring a more stable sediment surface took advantage in the absence of Arenicola. This implies that abundant lugworms would suppress a turf-building Vaucheria. Accordingly, we only found Vaucheria at the lower shore around spring low tide level, where lugworms are very large but few. However, whether this is due to the distribution of lugworms or to an inherent avoidance by the species $V$. cf. velutina to low tide exposure of $>1 \mathrm{~h}$, should be tested by transplant experiments.

How could a small and slender alga displace much bigger lugworms? We observed (Reise et al. 2022) initial growth of Vaucheria on slightly elevated sand waves at the lower shore adjacent to already established beds (see also Fig. 1C). At such ridges, deposition prevails over erosion, and this may offer a window of opportunity for the invader. Once Vaucheria established anchorage, its growth habit may constitute a preadaptation to displace lugworms. We suggest the key mechanism is clogging feeding funnels with felted rhizoids and long filaments (Fig. 2C and E). These inhibit downward sliding of surface sediment and stay put in funnels. Clogging curtails the nutrition of lugworms. Instead of fueling microalgae at funnels with upwelling burrow water (Chennu et al. 2015), lugworms now supply Vaucheria with nutrients while this alga is inhibiting the downward slide of surface sediment. Shading of the sediment surface by a dense growth of Vaucheria may aggravate the situation. This would inhibit diatom growth at sediment surface, a major food of lugworms (Rijken 1979; Retraubun et al. 1996; Engel et al. 2012).

For the inverse relationship of Arenicola versus Vaucheria (Fig. 4), the causes began subtle on sand waves at the bare sand flat. Then became significant once a mosaic of plateaus with dense turf and bare pits with lugworms emerged in the course of June in 2020. In the old bed, conspicuous hummocks generated by Vaucheria alternated with troughs maintained by Arenicola. At the central part of the bed, almost all lugworms had vanished and the algal turf became coherent.

Antagonistic mechanisms between intertidal seagrass Zostera and Arenicola may support this interpretation. Seagrass with a mesh of roots and narrow blades is much larger but otherwise similar to Vaucheria. At high lugworm density and sheltered conditions, bioturbation may suppress seed germination and young Zostera, while dense growth of seagrass may inhibit lugworm feeding by roots and by shading of benthic microalgae (Philippart 1994; Valdemarsen et al. 2011; Suykerbuyk et al. 2012; Goerlitz et al. 2015). Also sharp boundaries and mosaic patterns are common (Eklöf et al. 2011). Juvenile lugworms may aggregate in patches of seagrass when avoiding to intermingle with adults (own observations). For this ephemeral phenomenon, no correspondence occurred at sites with Vaucheria because juvenile lugworms rarely occur at the lower shore. Another antagonistic relation occurs between lugworms and clusters of Spartina grass at the upper shore (van Wesenbeeck et al. 2007).

Lugworm bioengineering intensity may reach a tipping point, probably conditional on ambient hydrodynamics, above which sediment-stabilizing Vaucheria have to give 
way to sediment destabilizing lugworms. This could explain the observed mosaic pattern. Plateaus with a dense algal turf alternate with bare sand bioturbated by lugworms. We show that lugworms moved away from plateaus and aggregated at bare pits between, while the overall abundance in the belt of young growth of Vaucheria remained unchanged. Apparently, lugworms did not leave the sediment to swim away. Aggregations at pits with concerted sediment reworking activity may in turn retard a further spread of young algae. The consequence are arising depositional plateaus generated by sediment-stabilizing algae, alternating with eroding pits still intensively reworked by lugworms.

Such a mosaic pattern is still conspicuous at the outer edge in the Vaucheria bed that already has established in the previous year (Reise et al. 2022). Here, muddy hummocks covered by dense turf alternate with deep troughs where lugworms persevere and the algal turf remains patchy. Nevertheless, at the oldest part of the bed, a coherent turf of particularly elongated algae prevails. There hummocks and troughs have leveled out. Most likely, this is an effect of preceding winter storms (Reise et al. 2022). In addition, at the central part of the bed, hydrodynamics is lower than at elevated edges. This may result in a more even deposition of fine organic particles and increasing sulfide concentrations in the sediment, adding unfavorably to clogging of lugworm feeding funnels and shading of benthic microalgae to the disadvantage of Arenicola. Such a complete displacement of lugworms may take 3 years, because the mosaic pattern of the antagonists slows down the takeover of Vaucheria. This is inferred from two layers of dead algal filaments at the central meadow and from aerial images, which suggest absence of Vaucheria prior to 2018 at that site (Reise et al. 2022). Where hydrodynamic conditions are stronger, the mosaic pattern may even perpetuate, as observed by us at another site.

Mosaic patterns are a recurrent phenomenon caused by aggregate settlement, large individuals shadowing or displacing those of other species or by clonal growth of plants or colonial animals. This spatial organization may be dynamic due to limited longevity or disturbances or remain in a quasi-permanent state (Remmert 1991; Rietkerk and van de Koppel 2008; van de Vijsel et al. 2020). The mosaic of an introduced Vaucheria alternating with resident Arenicola demonstrates that such patterns emerge spontaneously and do not require joint evolutionary history. Hardly discernable, parallel sand waves separated by slight depressions may predetermine the scale of mosaic patches. Both, Vaucheria and Arenicola respond to these in opposite ways and then modify and reinforce the pattern by antagonistic bioengineering and positive feedbacks.

Could the invading Vaucheria endanger the entire lugworm population? We do not assume that displacement of 'senior' lugworms around spring low tide level would be a threat to the entire lugworm population in the Wadden Sea. Even if these largest worms could contribute disproportionally to gamete production, their effect on population size would be marginal because of density dependence where abundances are high (Flach and Beukema 1994; Reise et al. 2001).

\section{Provision of novel habitat}

What does a dense turf of a small alga offer to associated fauna? The novel habitat provided by Vaucheria functions as a nursery for juveniles of the intertidal macrofauna when still of meiofaunal size. These show a clear preference for the algal turf. Altogether, we found ten species of young bivalves in the algal turf and only one at the bare sand of the lugworm flat. Of particular abundance were juveniles of the small mud snail Peringia ulvae with up to ten individuals per $\mathrm{cm}^{2}$ in June, crawling at the green filaments and feeding on epiphytic, sessile diatoms and on the occasionally adhering green alga Rhizoclonium riparium but not on Vaucheria (own observation). This constitutes a spontaneous mutual benefit for Vaucheria. P. ulvae keeps the filaments clean and benefits from easily accessible food.

Juvenile macrofauna likely found shelter in the algal turf against epibenthic predators such as shrimp (Crangon crangon). Tube-dwelling spionid polychaetes occurred with more than two individuals per $\mathrm{cm}^{2}$ in dense algal turf, and Streblospio benedicti did not occur elsewhere. In addition to shelter against epibenthic predators, also the sediment-stabilizing effect of Vaucheria could be beneficial. On tidal flats in the Firth of Forth (Scotland) with a low density of lugworms a similar preference of spionid polychaetes for patches of Vaucheria was observed, comprising even the same species as we found (Pygospio elegans, Polydora cornuta and Streblospio benedicti) (Bolam and Fernandes (2002; pers. communication).

Of special interest is the obligatory feeding of the tiny sea slug Alderia modesta on cushions or turfs of Vaucheria (Hartog 1959; Seelemann 1967; Rasmussen 1973; Ligthart 2009). Similar to Elysia, also A. modesta saves chloroplasts from their diet for photosynthesis on their own (kleptoplasty: Clark et al. 1990; Rumpho et al. 2011). With the appearance of Vaucheria at the lower shore of the Wadden Sea, A. modesta could widen its narrow niche at salt marshes of the upper shore considerably. This was also observed in the Oosterschelde (Rhine delta) where Vaucheria longicaulis is spreading since 1993 (Ligthart 2009). Whether A. modesta would be capable of stopping the Vaucheria invasion at the lower shore needs further investigation. In summer 2020, its abundances were too low for thinning out algal turfs. The role of other mesoherbivores such as gammarid amphipods also needs further 
attention. Large herbivores, such as Brent geese or widgeon were not yet observed grazing at low shore Vaucheria.

On close investigation, a cocktail of inhibiting, neutral and facilitating effects on residents may always be the case with invaders (Thieltges et al. 2006). Superficially, there is some similarity of the Vaucheria turf with episodic mats of green algae on tidal flats in response to eutrophication. These mats suffocated endobenthic fauna underneath, but provided habitat to opportunists and epibenthic snails such as Peringia ulvae (i.e., Nicholls et al. 1981; Reise 1983; Raffaelli et al. 1999; Bolam et al. 2000). However, Vaucheria is not ephemeral and attract a rich small fauna (Bolam and Fernandes 2002; this study). This follows the generalization of Crooks (2002) that invaders increasing habitat complexity entail higher abundances and species richness in residents. The occasionally accumulating drift algae in the Vaucheria bed may contribute to import and export of mobile epifauna, enhancing species diversity.

Although leaves of seagrass are taller and broader and roots go deeper than in Vaucheria, effects of Zostera on associated fauna are strikingly similar, i.e., high abundances of tube-building spionid polychaetes and epibenthic mud snails (i.e., Reise 1978; Orth et al. 1984; Reise et al. 1994; Philippart 1995) and inhibition of lugworms (see above). We observed no mixing of seagrass beds and Vaucheria. Although expanding Vaucheria beds at the lower shore cannot serve as a substitute for declining beds of Zostera at the upper shore of northern Sylt (see Dolch and Reise 2010), the similarity of effects on associated fauna suggests some kind of compensation.

\section{Conclusions and outlook}

We present evidence that an alien alga is capable of displacing a resident keystone bioengineer at the lower shore of the Wadden Sea. Conversely, where lugworm density is high, spread of Vaucheria may be inhibited. In the first summer of invasion, Vaucheria and Arenicola arrange in a mosaic fashion on m-scale. In the course of the second summer of Vaucheria establishment, lugworms vanish where Vaucheria forms continuous turfs. A habitat of bare loose sand and reworked by lugworms is transformed into bumpy mud, held together by a felt of rhyzoids and covered by a dense turf of thin filaments. We speculate that Vaucheria could eventually displace lugworms entirely from lower shores, while other benthos finds shelter under a filamentous canopy, also benefitting from stabilized sediment or algal food. Presumably, the invasion will proceed, as there is ample bare sandy sediment at the lower shore equivalent to what has already been vegetated near the island of Sylt.
Acknowledgements The staff of Wadden Sea Station Sylt, AlfredWegener-Institut, Helmholtz-Zentrum für Polar- und Meeresforschung gave substantial support in many ways in the course of this study. Nataliya Rybalka and Rune Michaelis kindly read and improved the manuscript, as did three highly dedicated reviewers.

Author contributions The study was conducted and written by KR and DL; KMW conducted statistical analyses and commented on the manuscript.

Funding Open Access funding enabled and organized by Projekt DEAL. Funding was not received.

Data availability All data generated and analyzed during this study are included in this published article.

\section{Declarations}

Conflict of interest The authors declare that they have no conflicts of interest.

Ethical approval This study does not comprise animals that are regulated under national or EU ethical guidelines.

Open Access This article is licensed under a Creative Commons Attribution 4.0 International License, which permits use, sharing, adaptation, distribution and reproduction in any medium or format, as long as you give appropriate credit to the original author(s) and the source, provide a link to the Creative Commons licence, and indicate if changes were made. The images or other third party material in this article are included in the article's Creative Commons licence, unless indicated otherwise in a credit line to the material. If material is not included in the article's Creative Commons licence and your intended use is not permitted by statutory regulation or exceeds the permitted use, you will need to obtain permission directly from the copyright holder. To view a copy of this licence, visit http://creativecommons.org/licenses/by/4.0/.

\section{References}

Anton A, Geraldi NR, Lovelock CE, Apostolaki ET, Bennett S et al (2019) Global ecological impacts of marine exotic species. Nature Ecol Evol 3:787-800. https://doi.org/10.1038/s41559-019-0851-0

Bailey SA, Brown L, Campbell ML, Canning-Clode J, Carlton JT et al (2020) Trends in the detection of aquatic non-indigenous species across global marine, estuarine and freshwater ecosystems: a 50-year perspective. Divers Distrib 26:1780-1797

Beukema JJ, de Vlas J (1979) Population parameters of the lugworm, Arenicola marina, living on tidal flats in the Dutch Wadden Sea. Neth J Sea Res 13:331-353. https://doi.org/10.1016/00777579(79)90010-3

Bolam SG, Fernandes TF (2002) The effects of macroalgal cover on the spatial distribution of microbenthic invertebrates: the effect of macroalgal morphology. Hydrobiologia 475(476):437-448. https://doi.org/10.1023/A\%3A1020307929624

Bolam SG, Fernandes TF, Read P, Raffaelli D (2000) Effects of macroalgal mats on intertidal sandflats: an experimental study. J Exp Mar Biol Ecol 249:123-137. https://doi.org/10.1016/s00220981(00)00185-4 
Buschbaum C, Lackschewitz D, Reise K (2012) Nonnative macrobenthos in the Wadden Sea ecosystem. Ocean Coast Manag 68:89101. https://doi.org/10.1016/j.ocecoaman.2011.12.011

Cadée GC (1976) Sediment reworking by Arenicola marina on tidal flats in the Dutch Wadden Sea. Neth J Sea Res 10:440-460. https://doi.org/10.1016/0077-7579(76)90020-X

Chennu A, Volkenborn N, de Beer D, Wethey DS, Woodin SA, Polerecky L (2015) Effects of bioadvection by Arenicola marina on microphytobenthos in permeable sediments. PLoS ONE 10(7):e0134236. https://doi.org/10.1371/journal.pone.0134236

Christensen T (1996) Variation within the Vaucheria longicaulis complex (Tribophyceae), including previously unknown representatives from the northern Atlantic. Eur J Phycol 31:49-52. https:// doi.org/10.1080/09670269600651181

Clark KB, Jensen KR, Stirts HM (1990) Survey for functional kleptoplasty among West Atlantic Ascoglossa (=Sacoglossa) (Mollusca: Opisthobranchia). The Veliger 33:339-345

Crooks JA (2002) Characterizing ecosystem-level consequences of biological invasions: the role of ecosystem engineers. Oikos 97:152-166. https://doi.org/10.1034/j.1600-0706.2002.970201.x

Cuthbert RN, Pattison Z, Taylor NG, Verbrugge L, Diagne C et al (2021) Global economic costs of aquatic invasive alien species. Sci Total Env 775:145238

den Hartog CD (1959) Distribution and ecology of the slugs Alderia modesta and Limapontia depressa in the Netherlands. Beaufortia 7:15-36

Dolch T, Reise K (2010) Long-term displacement of intertidal seagrass and mussel beds by expanding large sandy bedforms in the northern Wadden Sea. J Sea Res 63:93-101. https://doi.org/10.1016/j. seares.2009.10.004

Eklöf JS, van der Heide T, Donadi S, van der Zee EM et al (2011) Habitat-mediated facilitation and counteracting ecosystem engineering interactively influence ecosystem responses to disturbance. PLoS ONE 6(8):e23229. https://doi.org/10.1371/journal. pone. 0023229

Engel M, Behnke A, Klier J, Buschbaum C et al (2012) Effects of the bioturbating lugworm Arenicola marina on the structure of benthic protistan communities. Mar Ecol Prog Ser 471:87-99. https:// doi.org/10.3354/meps 10008

Farke H, de Wilde PAWJ, Berghuis EM (1979) Distribution of juvenile and adult Arenicola marina on a tidal mud flat and the importance of nearshore areas for recruitment. Neth J Sea Res 13:354-361. https://doi.org/10.1016/0077-7579(79)90011-5

Flach EC (1992) Disturbance of benthic infauna by sediment-reworking activities of the lugworm Arenicola marina. Neth J Sea Res 30:81-89. https://doi.org/10.1016/0077-7579(92)90048-J

Flach EC, Beukema JJ (1994) Density-governing mechanisms in populations of the lugworm Arenicola marina on tidal flats. Mar Ecol Prog Ser 115:139-149. https://doi.org/10.3354/MEPS115139

Gallagher SB, Humm HJ (1981) Vaucheria (Xanthophyceae, Vaucheriaceae) of the Central Florida Gulf Coast. Bull Mar Sci 31:184-190

Gätje C, Reise K (1998) (eds) Ökosystem Wattenmeer. Austausch-, Transport- und Stoffumwandlungsprozesse. Springer, Berlin

Goerlitz S, Berkenbusch K, Probert PK (2015) Lugworm (Abarenicola affinis) in seagrass and unvegetated habitats. Helgol Mar Res 69:159-168. https://doi.org/10.1007/s10152-014-0424-1

Guy-Haim T, Lyons DA, Kotta J, Ojaveer H et al (2017) Diverse effects of invasive ecosystem engineers on marine biodiversity and ecosystem functions: a global review and meta-analysis. Glob Change Biol 2017:1-19. https://doi.org/10.1111/gcb.14007

Krieg H, Eller T, Kies L (1988) Verbreitung und Ökologie der Vaucheria-Arten (Tribophyceae) des Elbe-Ästuars und der angrenzenden Küste. Helgol Meeresunters 42:613-636. https://doi.org/10.1007/ BF02365631
Kuhnert J, Veit-Köhler G, Büntzow M, Volkenborn N (2010) Sediment-mediated effects of lugworms on intertidal meiofauna. J Exp Mar Biol Ecol 387:36-43. https://doi.org/10.1016/j.jembe. 2010.03.001

Lackschewitz D, Reise K (1998) Macrofauna on flood delta shoals in the Wadden Sea with an underground association between the lugworm Arenicola marina and the amphipod Urothoe poseidonis. Helgol Meeresunters 52:147-158. https://doi.org/10.1007/BF029 08744

Lackschewitz D, Reise K, Buschbaum C, Karez R (2015) Neobiota in deutschen Küstengewässern. LLUR Schleswig-Holstein, Flintbek, Germany

Lei Y, Stumm K, Volkenborn N, Wickham SA, Berninger UG (2010) Impact of Arenicola marina (Polychaeta) on the microbial assemblages and meiobenthos in a marine intertidal flat. Mar Biol 157:1271-1282. https://doi.org/10.1007/s0227-010-1407-7

Ligthart M (2009) Nieuw waarnemingen aan "het gewone kwelderslakje' Alderia modesta (Lovén, 1844) en, het kleine schorrenslakje' Limapontia depressa (Alder \& Hancock, 1862). Zeepaard 69:19-40

Nicholls DJ, Tubbs CR, Haynes FN (1981) The effects of green algal mats on intertidal macrobenthic communities and their predators. Kieler Meeresforsch Sonderh 5:511-520

Orth RJ, Heck KL, van Montfrans J (1984) Faunal communities in seagrass beds: a review of the influence of plant structure and prey characteristics of predator-prey relationships. Estuaries 7:339-350. https://doi.org/10.2307/1351618

Philippart CJM (1994) Interactions between Arenicola marina and Zostera noltii on a tidal flat in the Wadden Sea. Mar Ecol Prog Ser 111:251-257. https://www.jstor.org/stable/24849563

Philippart CJM (1995) Effect on periphyton grazing by Hydrobia ulvae on the growth of Zostera noltii on a tidal flat in the Dutch Wadden Sea. Mar Biol 122:431-437. https://doi.org/10.1007/ BF00350876

Polderman PJG (1979a) The saltmarsh algal communities in the Wadden area, with reference to their distribution and ecology in N.W. Europe. I. The distribution and ecology of the algal communities. J Biogeogr 6:225-266. https://doi.org/10.2307/3038178

Polderman PJG (1979b) The salt-marsh algae of the Wadden Sea. In: Wolff WJ (ed) Ecology of the Wadden Sea. Marine Botany 3/3, pp 124-160. Balkema, The Netherlands

Pyšek P, Hulme PE, Simberloff D, Bacher S, Blackburn TM et al (2020) Scientists' warning on invasive alien species. Biol Rev 95:1511-1534. https://doi.org/10.1111/brv.12627

R Core Team (2021) R: a language and environment for statistical computing. R Foundation for Statistical Computing, Vienna, Austria. https://www.R-project.org/.

Raffaelli D, Raven J, Poole L (1999) Ecological impacts of green macroalgal blooms. Aqu Conserv Mar Freshw Ecosyst 9:219-236. https://doi.org/10.1201/B12646-13

Rasmussen E (1973) Systematics and ecology of the Isefjord marine fauna (Denmark). Ophelia 11:265. https://doi.org/10.1080/00785 326.1973.10430115

Reise K (1978) Experiments on epibenthic predation in the Wadden Sea. Helgol Wiss Meeresunters 31:55-101. https://doi.org/10. 1007/BF02296991

Reise K (1983) Sewage, green algal mats anchored by lugworms and the effect on small Turbellaria and small Polychaeta. Helgol Meeresunters 36:151-162. https://doi.org/10.1007/BF01983854

Reise K (1985) Tidal flat ecology (ecological studies 54). Springer, Berlin, Heidelberg, New York

Reise K, Herre E, Sturm M (1994) Biomass and abundance of macrofauna in intertidal sediments of Königshafen in the northern Wadden Sea. Helgol Meeresunters 48:201-215. https://doi.org/ 10.1007/BF02367036 
Reise K, Simon M, Herre E (2001) Density-dependent recruitment after winter disturbance on tidal flats by the lugworm Arenicola marina. Helgol Mar Res 55:161-165. https://doi.org/10.1007/ s101520100076

Reise K, Baptist M, Burbdridge P, Dankers N, Fischer L, Flemming B, Oost AP, Smit C (2010) The Wadden Sea-a universally outstanding tidal wetland. In: Wadden Sea Ecosystem 29. Common Wadden Sea Secretariat, Wilhelmshaven, Germany, pp 7-24

Reise K, Michaelis R, Rybalka N (2022) Invading grass-like alga transforms rippled sand bars into bumpy mud flats: arrival of a game changer in the Wadden Sea? Aqu Invasions (accepted)

Remmert H (1991) The mosaic-cycle concept of ecosystems (ecological studies 85). Springer, Berlin

Retraubun ASW, Dawson M, Evans SM (1996) The role of the burrow funnel in feeding processes in the lugworm Arenicola marina. $\mathrm{J}$ Exp Mar Biol Ecol 202:107-118. https://doi.org/10.1016/00220981(96)00017-2

Rick JJ, Scharfe M, Romanova T, van Beusekom JEE et al (2022) An evaluation of long-term physical and hydrochemical measurements at the Sylt roads marine observatory (1973-2019), Wadden Sea, North Sea. Earth Syst Sci Data (preview)

Rietkerk M, van de Koppel J (2008) Regular pattern formation in real ecosystems. Trends Ecol Evol 23:169-175. https://doi.org/10. 1016/j.tree.2007.10.013

Riisgård HU, Banta GT (1998) Irrigation and deposit feeding by the lugworm Arenicola marina, characteristics and secondary effects on the environment: a review of current knowledge. Vie Milieu 48:243-257. https://hal.sorbonne-universite.fr/hal-03173003

Rijken M (1979) Food and food uptake in Arenicola marina. Neth J Sea Res 13:406-421. https://doi.org/10.1016/0077-7579(79)90014-0

Rumpho ME, Pelletreau KN, Moustafa A, Bhattacharya D (2011) The making of a photosynthetic animal. J Exp Biol 214:303-311. https://doi.org/10.1242/jeb.046540

Rybalka N, Epkes S, Wegner KM, Michaelis R, Reise K (2022) Invasive Vaucheria (Xanthophyceae) at the lower shore of the Wadden Sea. Phycologia (submitted)

Seelemann U (1967) Rearing experiments on the amphibian slug Alderia modesta. Helgol Wiss Meeresunters 15:128-134. https://doi. org/10.1007/BF01618615

Simons J (1975) Vaucheria species from estuarine areas in the Netherlands. Neth J Sea Res 9:1-23. https://doi.org/10.1016/00777579(75)90020-4

Sousa R, Gutiérrez JL, Aldridge DC (2009) Non-indigenous invasive bivalves as ecosystem engineers. Biol Invasions 11:2367-2385. https://doi.org/10.1007/s10530-009-9422-7

Stegenga H, Karremans M, Simons J (2006) Zeewieren van de voormalige osterputten bij Yerseke [Seaweeds of former oyster plots near Yerseke, Osterschelde, The Netherlands]. Gorteria 32:125-143

Suykerbuyk W, Bouma TJ, van der Heide T, Faust C, Govers LL et al (2012) Suppressing antagonistic bioengineering feedbacks doubles restoration success. Ecol Appl 22:1224-1231. https://doi.org/ $10.1890 / 11-1625.1$
Thieltges DW, Strasser M, Reise K (2006) How bad are invaders in coastal waters? The case of the American slipper limpet Crepidula fornicata in western Europe. Biol Invasions 8:1673-1680. https:// doi.org/10.1007/s10530-005-5279-6

Valdemarsen T, Wendelboe K, Egelund JT, Kristensen E, Flindt MR (2011) Burial of seeds and seedlings by the lugworm Arenicola marina hampers eelgrass (Zostera marina) recovery. J Exp Mar Biol Ecol 410:45-52. https://doi.org/10.1016/j.jembe.2011.10.006

van de Vijsel RC, van Belzen J, Bouma TJ, van der Wal D et al (2020) Estuarine biofilm patterns: Modern analogues for Precambrian self-organization. Earth Surf Proc Land 45:1141-1154. https:// doi.org/10.25850/nioz/7b.b.m

van Wesenbeeck B, van de Koppel J, Herman P, Bakker J, Bouma T (2007) Biomechanical warfare in ecology: negative interactions between species by habitat modification. Oikos 116(5):742-750. http://www.jstor.org/stable/40235117

Volkenborn N, Reise K (2007) Effects of Arenicola marina on polychaete functional diversity revealed by large-scale experimental lugworm exclusion. J Sea Res 57:78-88. https://doi.org/10.1016/j. seares.2006.08.002

Volkenborn N, Polerecky L, Hedtkamp SIC, van Beusekom JEE, de Beer D (2007) Bioturbation and bioirrigation extend the open exchange regions in permeable sediments. Limnol Oceangr 52:1898-1009. https://doi.org/10.4319/lo.2007.52.5.1898

Volkenborn N, Robertson DM, Reise K (2009) Sediment destabilizing and stabilizing bioengineers on tidal flats: cascading effects of experimental exclusion. Helgol Mar Res 63:27-35. https://doi. org/10.1007/s10152-008-0140-9

Wendelboe K, Egelund JT, Flindt MR, Valdemarsen T (2013) Impact of lugworms (Arenicola marina) on mobilization and transport of fine particles and organic matter in marine sediments. J Sea Res 76:31-38. https://doi.org/10.1016/j.seares.2012.10.013

Wilcox MD (2012) Occurrence of the marine yellow-green algae Vaucheria velutina C. Agardh and Vaucheria longicaulis Hoppaugh (Xanthophyceae: Vaucheriaceae) in Auckland, New Zealand. NZ J Mar Freshwat Res 46:285-290. https://doi.org/10. 1080/00288330.2011.622444

Womersley HBS (1987) The marine benthic flora of Southern Australia Part II. In: Handbook of the Flora \& Fauna of South Australia. South Australia Government Printing Division, Adelaide, pp 448-453

Zipperle A, Reise K (2005) Freshwater springs on intertidal sand flats cause a switch in dominance among polychaete worms. J Sea Res 54:143-150. https://doi.org/10.1016/j.seares.2005.01.003

Publisher's Note Springer Nature remains neutral with regard to jurisdictional claims in published maps and institutional affiliations. 